\title{
APPLICATION OF SYNTHETIC AND NATURAL POLYMERS IN PREPARATION AND CHARACTERIZATION OF DOMPERIDONE FAST-DISSOLVING FILMS
}

\author{
SARIPILLI RAJESWARI*, PATIBANDLA SAMEERA, KONCHADA ALEKHYA, KURALLA HARI
}

Department of Pharmaceutics, Maharajah's College of Pharmacy, Vizianagaram, Andhra Pradesh, India. Email: rajeswarimalli@gmail.com Received: 06 July 2019, Revised and Accepted: 19 August 2019

ABSTRACT

Objective: The present research work is mainly focused on solubility enhancement of domperidone which is a biopharmaceutical classification system Class II drug using natural and synthetic polymers.

Methods: The solubility was enhanced by the kneading method with the drug: polymer $(1: 0.5,1: 0.75$, and 1:1) using $\beta$-cyclodextrin. The fast dissolving films (FDFs) of domperidone were prepared by incorporating the solid dispersion (SD) SDK3 by solvent casting method using hydroxypropyl methylcellulose K15 M (HPMC) and gellan gum in various concentrations for preparing FDFs. Various pre- and post-compression parameters, drug and excipients compatibility studies were evaluated by Fourier transform infrared (FTIR) spectroscopy, differential scanning calorimetry (DSC), and X-ray diffraction analysis (XRD).

Results: The maximum drug release of $98.86 \%$ was achieved within 30 min for 1:1 ratio of solid dispersion using $\beta$-cyclodextrin, was optimized and taken for further development of FDFs. From the in vitro drug release studies films prepared with 10\% w/w of HPMC K 15 (FH5) and 10\% w/w of gellan gum (FG5) showed enhanced dissolution rate compared to other formulations. The formulation FHG with combination of polymers, namely, HPMC K 15 and gellan gum in 1:1 ratio showed drug release of $97.22 \%$ within 15 min only when compared with the optimized formulations. FTIR and DSC studies revealed that there were no interactions between drug and excipients. XRD studies revealed slight conversion of crystalline form to amorphous. The optimized formulation FHG found to be stable under accelerated stability studies.

Conclusions: The polymers in combination are a potential candidate for use in the formulation of FDF.

Keywords: Fast-dissolving film, Domperidone, Gellan gum, Hydroxypropyl methylcellulose, $\beta$-cyclodextrins, and Solid dispersion.

(C) 2019 The Authors. Published by Innovare Academic Sciences Pvt Ltd. This is an open access article under the CC BY license (http://creativecommons. org/licenses/by/4. 0/) DOI: http://dx.doi.org/10.22159/ajpcr.2019.v12i10.34800

\section{INTRODUCTION}

Among the different routes of administration, the oral route of administration continues to be most preferred route due to various advantages including ease of administration, avoidance of pain, versatility, and most importantly patient compliance [1]. Many drugs given orally are poor in bioavailability because of the $\mathrm{pH}$ of the stomach, the presence of enzymes and extensive first-pass metabolism. Recent development in novel drug delivery system aims to enhance the safety and efficacy of drug molecules by formulating a convenient dosage form for administration [2,3]. Fast-dissolving oral delivery systems are solid dosage forms, which disintegrate or dissolve within 1 min when placed in the mouth without drinking water or chewing. The development of solid dosage films is given in Fig. 1 [4].

FDFs are the dosage forms which readily releases the drug by dissolving or when it comes in contact with the wet surface without the need of intake of water when compared with tablet due to increase in its surface area [5]. A film or strip can be defined as a dosage form that employs a water dissolving polymer (generally a hydrocolloid, which may be a bio adhesive polymer), which allows the dosage form to instantly wet by saliva [6]. The film quickly hydrates, adheres, then rapidly disintegrates and dissolves to release the medication for mucosal and intra gastric absorption when placed on the tongue or in the oral cavity to provide rapid local or systemic drug delivery $[7,8]$. This technology is also applicable for administration of low dose drugs and unpalatable drugs (domperidone, atenolol etc.,) of Biopharmaceutical classification system (BCS) Class II drugs. In that case, for better release, the solubility of the drugs was improved by employing different solubility enhancement methods. One of the most commonly used techniques is solid dispersion (SD) which mainly includes different methods such as kneading method, neutralization method, solvent evaporation, and physical mixing [9-11]. Domperidone, a dopamine antagonist with an antiemetic and gastroprokinetic properties, is structurally related to the butyrophenones which do not cross the blood-brain barrier and mainly act on the chemotriger zone, located within the postrema zone [12]. The films are formulated using synthetic and hydrophilic polymers by employing kneading technique for solubility enhancement and solvent casting for the preparation of films [13].

\section{MATERIALS AND METHODS}

Materials

All materials used for the formulation were of analytical grade. Domperidone, $\beta$-cyclodextrin (CD), HPMC K4 M, HPMC K15 M, HPMC K100 M, gellan gum, glycerol citric acid, sodium starch glycolate, mannitol and Tween 80 were purchased from Yarrow Chem., Products, Mumbai. Ethanol from Changshu Yangyuan, China. Sodium hydroxide and potassium dihydrogen phosphate were purchased from Finar Limited, Ahmedabad.

\section{Method of preparation of SD}

SDs were prepared with the different ratios of 1:0.5, 1:0.75 and 1:1 by kneading, physical and neutailization methods and evaluated for their drug content, percentage yield and dissolution properties in comparison with their respective physical mixtures [14-19].

Preparation of domperidone FDFs using solvent casting method The formulation of domperidone FDFs is given in Table 1. The films were prepared by dissolving film forming polymers and plasticizer as main constituents in water, later on addition of other remaining excipients with active pharmaceutical ingredient was added to the prepared solution. Different batches of formulations FH1-FH5 were formulated using HPMC grades, formulations FG1-FG5 were formulated using gellan gum as polymers and glycerol as a plasticizer by dissolving in an appropriate amount of water, formulation FHG was prepared by taking combination of HPMC and gellan gum and stirred for $4 \mathrm{~h}$ by maintaining $2000 \mathrm{rpm}$ and kept aside for $1 \mathrm{~h}$ for the removal of entrapped air bubbles in the solution. Another solution was prepared by dissolving the other additives with Active pharmaceutical ingredient 
Table 1: Composition of formulations

\begin{tabular}{|c|c|c|c|c|c|c|c|c|c|c|c|}
\hline Ingredients (mg) & FH1 & FH2 & FH3 & FH4 & FH5 & FG1 & FG2 & FG3 & FG4 & FG5 & FHG \\
\hline Ratio of API: CD & 10 & 10 & 10 & 10 & 10 & 10 & 10 & 10 & 10 & 10 & 10 \\
\hline Hydroxypropyl methylcellulose K15 & 16 & 14 & 12 & 10 & 8 & - & - & - & - & - & 4 \\
\hline Gellan gum & - & - & - & - & - & 16 & 14 & 12 & 10 & 8 & 4 \\
\hline Citric acid & 4 & 4 & 4 & 4 & 4 & 4 & 4 & 4 & 4 & 4 & 4 \\
\hline Sodium starch glycolate & 6 & 6 & 6 & 6 & 6 & 6 & 6 & 6 & 6 & 6 & 6 \\
\hline Mannitol & 4 & 4 & 4 & 4 & 4 & 4 & 4 & 4 & 4 & 4 & 4 \\
\hline Tween 80 & 4 & 4 & 4 & 4 & 4 & 4 & 4 & 4 & 4 & 4 & 4 \\
\hline
\end{tabular}

\begin{tabular}{|c|c|c|c|}
\hline $\begin{array}{l}\text { Conventional solid } \\
\text { dosage forms } \\
\text { (tablets, capsules) }\end{array}$ & $\begin{array}{l}\text { Modified } \\
\text { release (tablets/ } \\
\text { capsules) }\end{array}$ & $\begin{array}{c}\text { Fast } \\
\text { dissolving } \\
\text { tablets }\end{array}$ & $\begin{array}{c}\text { Fast } \\
\text { dissolving } \\
\text { films }\end{array}$ \\
\hline
\end{tabular}

Fig. 1: Represents the development of solid dosage films

(API) in a hydro alcoholic solution and slowly added into the first solution and continued stirring for $1 \mathrm{~h}$ [20,21]. After completion of stirring, the solution was kept a side until the bubble free solution was obtained. Later, it was poured in Petri plate for obtaining the film and air-dried, as shown in Fig. 2.

Quantity sufficient of ethanol and water is taken for all formulations.

\section{Characterization of prepared SD}

The prepared SDs were evaluated for their drug content, percentage yield, and dissolution studies.

\section{Determination of drug content}

SD equivalent to $10 \mathrm{mg}$ of domperidone was weighed accurately and was transferred to a $50 \mathrm{ml}$ volumetric flask separately [1]. Volume was made up to $50 \mathrm{ml}$ with methanol and subjected to sonication for dissolving domperidone. Appropriate dilutions were made with pH 6.8 phosphate buffer, and the amount of domperidone was observed in spectrophotometer (ElicoUV-1700 ultraviolet (UV)/visible double beam spectrophotometer) at $284 \mathrm{~nm}$. The assay on each sample is replicated for 3 times. The drug content was calculated using Equation 1.

$$
\% \text { Drugcontent }=\frac{\text { Actualdrug content }}{\text { Theriticaldrugcontent }} \times 100
$$

\section{Determination of percent yield}

The percent yield of prepared SDs was determined by utilizing the formula given in Equation 2 using the total recoverable final weight of $\mathrm{SD}$ and the total original weights of drug and carriers used [22].

$$
\text { Percent yield }=\left[\frac{\mathrm{a}}{(\mathrm{b}-\mathrm{c})}\right] \times 100
$$

\section{In vitro dissolution studies}

The drug release from the prepared SD was studied using eight station dissolution rate test apparatus (Lab India, Disso 2000) employing a paddle stirrer at $75 \mathrm{rpm}$ and at $37 \pm 0.5^{\circ} \mathrm{C}$. Phosphate buffer of $\mathrm{pH} 6.8(900 \mathrm{ml})$ was used as dissolution fluid. At predetermined intervals, the aliquots sample was withdrawn and replaced with fresh media. The absorbance of these solutions was measured at $284 \mathrm{~nm}$ using spectrophotometer. The same process was used for domperidone FDFs.

\section{Evaluation of domperidone FDFs}

All the prepared domperidone FDFs were evaluated for thickness, dry test/tack test, tensile strength, percent elongation, tear resistance, Young's modulus, folding endurance, swelling properties, transparency, content uniformity, disintegration time, and in vitro dissolution test [23-25].

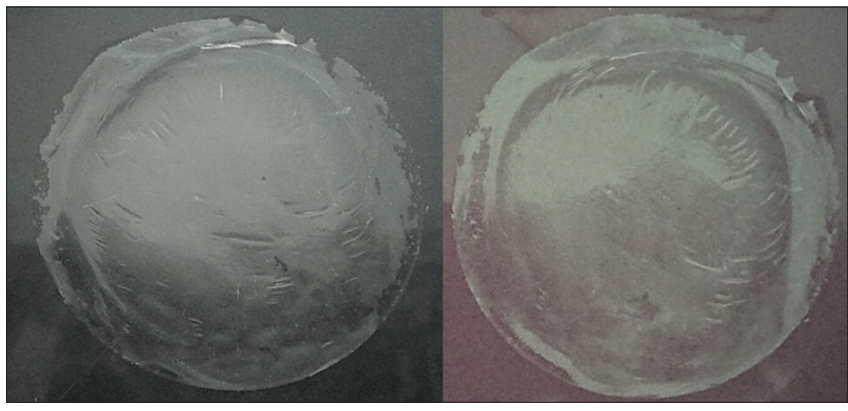

Fig. 2: Prepared domperidone FDFs

\section{Thickness}

The thickness of the strip can be measured by Vernier calipers at different strategic locations. This is essential to ascertain uniformity in the thickness of the film as this is directly related to the accuracy of dose in the strip.

\section{Percent elongation}

When stress is applied, a strip sample stretches, and this is referred to as strain. Strain is basically the deformation of strip divided by original dimension of the sample, as given in Equation 3. In general, elongation of strip increases as the plasticizer content increases.

$$
\% \text { Elongation }=\frac{\text { Increasein length of strip }}{\text { Initiallength of strip }} \times 100
$$

\section{Folding endurance}

Folding endurance is determined by repeated folding of the strip at the same place until the strip breaks. The number of times the film is folded without breaking is computed as the folding endurance value.

\section{Swelling property}

Film sample is weighed and placed in a pre-weighed stainless-steel wire mesh. The mesh containing a film sample is submerged into $15 \mathrm{ml}$ medium in a plastic container. The weight of the film was measured after the preset time interval after attaining of constant weight. The degree of swelling is calculated using formula:

$$
\alpha=\frac{W_{t}-W_{0}}{W_{0}}
$$

Where: $W_{t}$ is weight of film at time $t$ and $W_{o}$ is weight of film at time zero. 
Transparency

The film samples were cut into rectangles and placed on the internal side of the UV spectrophotometer cell and the transmittance of films was analyzed at $600 \mathrm{~nm}$. The transparency of the films can be calculated as follows:

$$
\text { Transparency }=\frac{\log \mathrm{T}_{600}}{\mathrm{~b}}=-€ \mathrm{c}
$$

Where: $\mathrm{T}_{600}$ is the transmittance at $600 \mathrm{~nm}, \mathrm{~b}$ is the film thickness $(\mathrm{mm})$, and $\mathrm{c}$ is concentration.

Table 2: Percent drug content and percent yield of prepared solid dispersions

\begin{tabular}{llll}
\hline $\begin{array}{l}\text { Drug: Beta } \\
\text { cyclodextrins mass } \\
\text { ratio }\end{array}$ & $\begin{array}{l}\text { Formulation } \\
\text { code }\end{array}$ & $\begin{array}{l}\text { Drug } \\
\text { content (\%)* }\end{array}$ & $\begin{array}{l}\text { Percent } \\
\text { yield* }\end{array}$ \\
\hline $1: 0.5$ & SDK1 & $89.34 \pm 0.25$ & $83.77 \pm 0.52$ \\
$1: 0.75$ & SDK2 & $93.48 \pm 0.32$ & $85.97 \pm 0.38$ \\
$1: 1$ & SDK3 & $96.86 \pm 0.08$ & $94.5 \pm 0.32$ \\
\hline
\end{tabular}

*Mean percent of domperidone released and obtained (mean \pm SD $(n=3))$

Table 3: Correlation coefficient analysis of formulations

\begin{tabular}{lllll}
\hline $\begin{array}{l}\text { Formulation } \\
\text { code }\end{array}$ & \multicolumn{4}{l}{ Correlation coefficient (r-value) } \\
\cline { 2 - 5 } & $\begin{array}{l}\text { Zero-order } \\
\text { model }\end{array}$ & $\begin{array}{l}\text { First-order } \\
\text { model }\end{array}$ & $\begin{array}{l}\text { Higuchi } \\
\text { model }\end{array}$ & $\begin{array}{l}\text { Erosion } \\
\text { plot }\end{array}$ \\
\hline PD & 0.9014 & 0.9525 & 0.9859 & 0.9375 \\
SDK1 & 0.9009 & 0.9533 & 0.9905 & 0.9381 \\
SDK2 & 0.7132 & 0.8353 & 0.8805 & 0.7921 \\
SDK3 & 0.6893 & 0.9472 & 0.8734 & 0.8539 \\
\hline
\end{tabular}

Content uniformity

Content uniformity was determined by estimating the domperidone content in an individual strip using $\mathrm{pH} 6.8$ phosphate buffer suitably diluted and the amount of drug present was estimated at $284 \mathrm{~nm}$ using UV spectrophotometer.

\section{Disintegration time}

The formulated films were subjected to the disintegration test using standard apparatus as mentioned in the reference pharmacopeias using $\mathrm{pH} 6.8$ phosphate buffer.

\section{Drug excipient compatibility studies}

Visual inspection

The compatibility of the drug and excipients was observed by visual inspection by placing the appropriate amount of the drug alone or in combination with other excipients in glass vials for about 3 months.

\section{Fourier transform infrared (FTIR) spectroscopy}

The interaction between drugs and excipients was investigated with the help of FTIR spectrophotometer (Shimadzu, Japan, FTIR-8400S). Test samples were placed in the side $\mathrm{KBr}$ discs (with a ratio of 1:100 of test sample within $\mathrm{KBr}$ was maintained) and compressed at applied hydrostatic pressure of $5.2 \mathrm{~N} / \mathrm{m}^{2}$ for about $180 \mathrm{~s}$. The range of scanning was between 400 and $4000 \mathrm{~cm}^{-1}$.

Differential scanning calorimetry (DSC)

DSC is generally used to investigate and predict any physicochemical interactions between components in the formulation and therefore can be applied to the selection of suitable chemically compatible excipients. The DSC analysis of pure drug and the excipients was carried out to evaluate any possible drug-polymer interactions. The analysis was

Table 4: Drug release characteristics of the prepared solid dispersions

\begin{tabular}{lllllll}
\hline Formulation code & Polymer concentration $\mathbf{( \% )}$ & $\mathbf{T}_{\mathbf{5 0}}(\mathbf{m i n})$ & $\mathbf{T}_{\mathbf{9 0}}(\mathbf{m i n})$ & $\mathbf{K}_{\mathbf{0}}(\mathbf{m g} / \mathbf{h})$ & $\mathbf{K}_{\mathbf{1}} / \mathbf{h}$ & $\mathbf{~ ' n ' ~ i n ~ P e p p a s ~ e q u a t i o n ~}$ \\
\hline PD & - & 30 & $>60$ & 0.9786 & 0.0067 \\
SDK1 & $1: 0.5$ & 12.5 & $>60$ & 0.9547 & 0.5952 \\
SDK2 & $1: 0.75$ & 9.5 & 43 & 1.4114 & 0.0171 \\
SDK3 & $1: 1$ & 7.5 & 15 & 1.5129 & 0.5169 & 0.5566 \\
\hline
\end{tabular}

Table 5: Film properties of formulations

\begin{tabular}{|c|c|c|c|c|c|}
\hline Evaluation parameters & FH1 & FH2 & FH3 & FH4 & FH5 \\
\hline$\%$ Drug content ${ }^{\mathrm{a}}$ & $97.51 \pm 0.89$ & $98.04 \pm 0.74$ & $98.32 \pm 1.18$ & $97.89 \pm 0.46$ & $98.69 \pm 0.98$ \\
\hline Thickness $^{\mathrm{b}}$ & $0.23 \pm 0.08$ & $0.21 \pm 0.15$ & $0.23 \pm 0.12$ & $0.23 \pm 0.18$ & $0.22 \pm 0.09$ \\
\hline Weight variation ${ }^{\mathrm{b}}$ & $58.45 \pm 0.08$ & $59.18 \pm 0.96$ & $58.33 \pm 0.54$ & $57.67 \pm 0.43$ & $57.89 \pm 0.88$ \\
\hline Surface $\mathrm{pH}^{\mathrm{a}}$ & $6.92 \pm 0.13$ & $6.78 \pm 0.11$ & $6.96 \pm 0.14$ & $6.84 \pm 0.12$ & $6.25 \pm 0.16$ \\
\hline Folding endurance $^{a}$ & $256 \pm 1.13$ & $242 \pm 0.52$ & $338 \pm 0.32$ & $286 \pm 0.67$ & $318 \pm 0.34$ \\
\hline Swelling property ${ }^{\mathrm{a}}$ & $0.42 \pm 0.14$ & $0.64 \pm 0.04$ & $0.45 \pm 0.06$ & $0.78 \pm 0.05$ & $0.76 \pm 0.08$ \\
\hline Transparency $^{\mathrm{a}}$ & Transparent & Transparent & Transparent & Transparent & Transparent \\
\hline$\%$ Elongation $^{\mathrm{a}}$ & $69.27 \pm 0.87$ & $54.65 \pm 0.32$ & $52.65 \pm 0.78$ & $32.67 \pm 0.34$ & $24.56 \pm 0.96$ \\
\hline
\end{tabular}

Where: ${ }^{a}$ mean \pm s.d. $(n=3)$ of domperidone FDFs, ${ }^{\text {b mean }} \pm$ s.d. $(n=10)$ of domperidone FDFs

Table 6: Film properties of formulations

\begin{tabular}{|c|c|c|c|c|c|c|}
\hline Evaluation parameters & FG1 & FG2 & FG3 & FG4 & FG5 & FHG \\
\hline$\%$ Drug Content ${ }^{\mathrm{a}}$ & $98.2 \pm 1.11$ & $98.4 \pm 0.78$ & $97.8 \pm 0.68$ & $98.9 \pm 0.46$ & $98.6 \pm 0.32$ & $98.9 \pm 0.88$ \\
\hline Thickness $^{\mathrm{b}}$ & $0.21 \pm 0.08$ & $0.22 \pm 0.01$ & $0.22 \pm 0.07$ & $0.23 \pm 0.06$ & $0.22 \pm 0.11$ & $0.22 \pm 0.05$ \\
\hline Weight variation $^{\mathrm{b}}$ & $58.2 \pm 0.42$ & $58.7 \pm 1.05$ & $58.8 \pm 0.95$ & $58.2 \pm 0.89$ & $57.9 \pm 0.76$ & $58.3 \pm 0.52$ \\
\hline Surface $\mathrm{pH}^{\mathrm{a}}$ & $6.52 \pm 0.12$ & $6.76 \pm 0.08$ & $6.63 \pm 0.11$ & $6.70 \pm 0.05$ & $6.90 \pm 0.10$ & $6.43 \pm 0.04$ \\
\hline Folding Endurance ${ }^{a}$ & $302 \pm 0.92$ & $295 \pm 0.54$ & $287 \pm 0.67$ & $312 \pm 0.83$ & $298 \pm 0.32$ & $308 \pm 0.53$ \\
\hline Swelling property ${ }^{\mathrm{a}}$ & $0.49 \pm 0.03$ & $0.68 \pm 0.05$ & $0.75 \pm 0.05$ & $0.59 \pm 0.02$ & $0.84 \pm 0.04$ & $0.86 \pm 0.06$ \\
\hline Transparency $^{\mathrm{a}}$ & Transparent & Transparent & Transparent & Transparent & Transparent & Transparent \\
\hline$\%$ Elongation $^{\mathrm{a}}$ & $59.8 \pm 0.56$ & $69.8 \pm 0.85$ & $64.7 \pm 0.43$ & $51.8 \pm 0.60$ & $25.7 \pm 0.64$ & $28.93 \pm 0.49$ \\
\hline
\end{tabular}

Where: ${ }^{a}$ mean \pm s.d. $(\mathrm{n}=3)$ of domperidone FDFs, ${ }^{b}$ mean \pm s.d. $(\mathrm{n}=10)$ of domperidone FDFs 
performed at a rate of $40^{\circ} \mathrm{C} / \mathrm{min}$ conducted over a temperature range of $40-300^{\circ} \mathrm{C}$.

\section{$X$-Ray diffraction analysis (XRD)}

XRD analysis is an important tool investigation tool for evaluating the crystal structure as well as the average structural spacing between the layers and rows of atoms in an unknown material. Both for pure drug and the drugloaded films, XRD studies were performed utilizing an XRD (Rigaku, Japan). A $400 \mathrm{kV}, 30 \mathrm{~mA} \mathrm{Cu}-\mathrm{K} \alpha$ radiations were maintained at a scanning speed of $10 /$ min to identify the physical state of drug as well as drug-loaded films.

\section{Data analysis}

Release data were analyzed as per zero-order, first-order, Higuchi, and Peppas equation models to assess the drug release kinetics and mechanism from the matrix tablets prepared [26,27].

\section{Stability studies}

The optimized formulations were accurately weighed, the amount of sample was placed in glass vials and stored for 1-3 months and

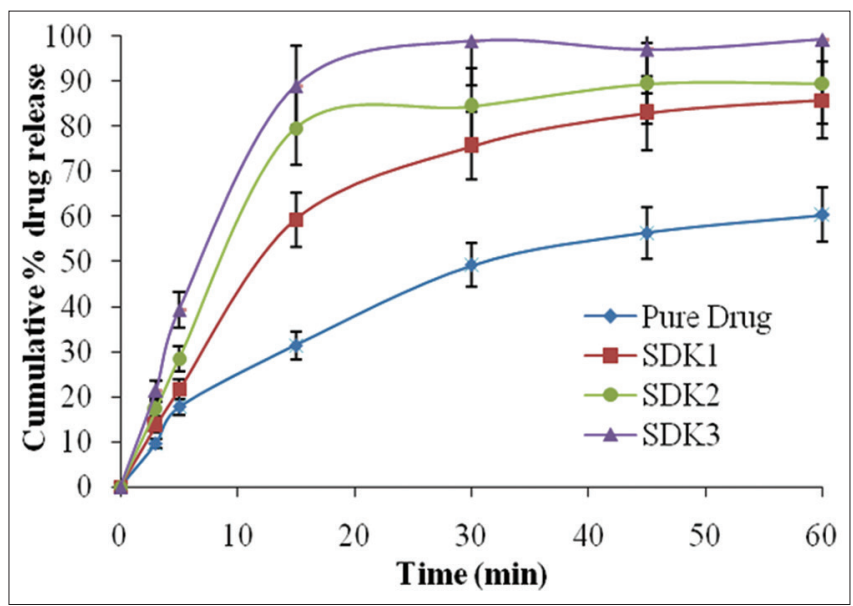

Fig. 3: Dissolution profiles of SD formulations evaluated for physical parameters, drug content and drug release studies.

\section{RESULTS AND DISCUSSION}

All the prepared SDs by kneading method showed free-flowing. The values of $\%$ drug content and \% yield are given in Table 2 and were found to be in the range of $89.34-96.86 \%$ and $83.77-94.5 \%$, respectively. The drug content analysis indicated that domperidone was uniformly distributed in the SDs prepared by kneading method.

The in vitro dissolution profiles, as shown in Fig. 3, have shown distinct deviation in the plots, when the concentration of polymer is increased the \%drug release was increased from $85.73,89.48$, and $99.29 \%$.

The correlation coefficient ( $r$ ) values in the analysis of the release data are given in Table 3 . The release data indicated that the domperidone release from the SDs followed first-order kinetics with diffusion controlled. When the release data were analyzed as per Peppas equation, the release exponent " $n$ " was in the range 0.51-0.59 indicating nonFickian (anomalous) diffusion as the release mechanism and values are given in Table 4. From the results, formulation SDK3 is optimized.

\section{Evaluation of domperidone FDFs}

The prepared domperidone FDFs were evaluated for thickness, percent elongation, folding endurance, swelling property, transparency, \%drug content, weight variation, surface $\mathrm{pH}$, disintegration time and in vitro dissolution studies. The results are shown in Tables 5 and 6.

\section{In vitro dissolution studies of FDFs}

All the formulations were evaluated for in vitro dissolution. As the concentration of the polymers, HPMC K15M and gellan gum increased the swelling of the film, disintegration time increased and \%drug release retarded. At lower concentration, the disintegration time decreased and $\%$ drug release increased within $20 \mathrm{~min}$. Hence, formulation with lower concentration of polymer was optimized and adopted in the preparation of FDFs to achieve the aim of the present research work. The drug release profiles are shown in Fig. 4. The drug release data were analyzed as per zero-order, first-order, Higuchi, Erosion, and Peppa's equation models. The correlation coefficient $(\mathrm{r}$ ) values in the analysis of the release data as

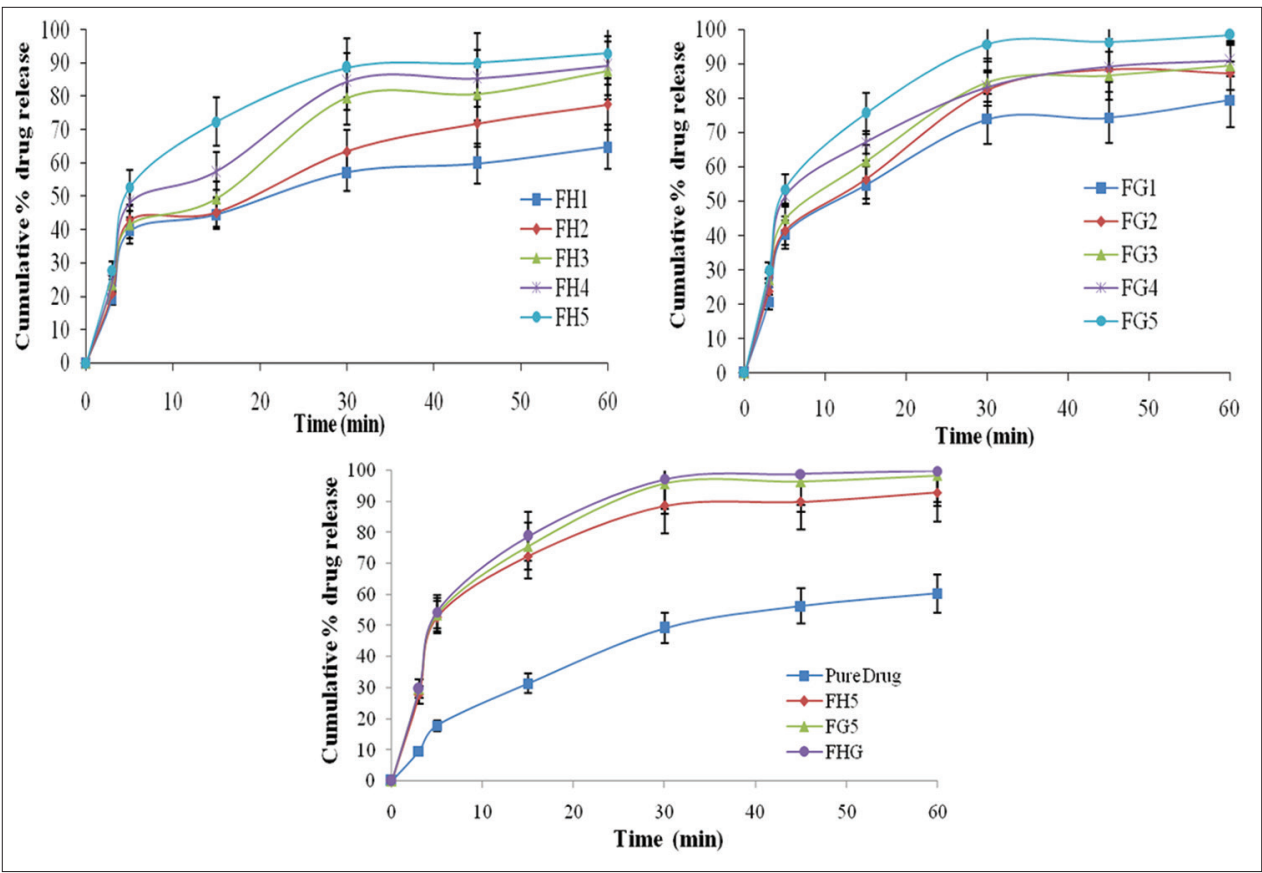

Fig. 4: Dissolution profiles of FDFs formulations 
Table 7: Correlation coefficient analysis of formulations

\begin{tabular}{lllll}
\hline $\begin{array}{l}\text { Formulation } \\
\text { code }\end{array}$ & \multicolumn{4}{l}{ Correlation coefficient (r-value) } \\
\cline { 2 - 5 } & $\begin{array}{l}\text { Zero-order } \\
\text { model }\end{array}$ & $\begin{array}{l}\text { First-order } \\
\text { model }\end{array}$ & $\begin{array}{l}\text { Higuchi } \\
\text { model }\end{array}$ & $\begin{array}{l}\text { Erosion } \\
\text { plot }\end{array}$ \\
\hline FH 1 & 0.7167 & 0.8301 & 0.8974 & 0.7941 \\
FH 2 & 0.7980 & 0.9301 & 0.9387 & 0.8928 \\
FH 3 & 0.8128 & 0.9393 & 0.9522 & 0.9071 \\
FH 4 & 0.7570 & 0.9089 & 0.9245 & 0.8686 \\
FH 5 & 0.6950 & 0.9027 & 0.8927 & 0.8424 \\
\hline
\end{tabular}

Table 8: Correlation coefficient analysis of formulations

\begin{tabular}{lllll}
\hline $\begin{array}{l}\text { Formulation } \\
\text { code }\end{array}$ & \multicolumn{3}{l}{ Correlation coefficient (r-value) } & \\
\cline { 2 - 5 } & $\begin{array}{l}\text { Zero-order } \\
\text { model }\end{array}$ & $\begin{array}{l}\text { First-order } \\
\text { model }\end{array}$ & $\begin{array}{l}\text { Higuchi } \\
\text { model }\end{array}$ & $\begin{array}{l}\text { Erosion } \\
\text { plot }\end{array}$ \\
\hline FG 1 & 0.7577 & 0.8828 & 0.9288 & 0.8462 \\
FG 2 & 0.7888 & 0.9063 & 0.9460 & 0.8785 \\
FG 3 & 0.7586 & 0.9149 & 0.9336 & 0.8728 \\
FG 4 & 0.7252 & 0.9291 & 0.9111 & 0.8718 \\
FG 5 & 0.7072 & 0.9499 & 0.9018 & 0.8861 \\
FHG & 0.6986 & 0.9912 & 0.8959 & 0.9202 \\
\hline
\end{tabular}

per different kinetic models are given in Tables 7 and 8. All the prepared formulation FH1-FH5, FG1-FG5, and FHG followed first-order kinetics. According to Korsmeyer-Peppas equation, the release exponent " $n$ " value was used to characterize different release mechanisms. If the $n$ value is 0.45 , the release mechanism follows Fickian diffusion. If $\mathrm{n}$ value is $0.45<\mathrm{n}>0.89$ (for cylindrical), the mechanism follows non-Fickian (anomalous) diffusion, and when $n$ value is 0.89 it will be non-Fickian case II transport, and if $n>0.89$ it will be non-Fickian super case II transport. The drug release characteristics of the prepared domperidone FDFs are given in Tables 9 and 10. All the formulations followed nonFickian (anomalous) diffusion mechanism.

\section{Compatibility studies of FDFs \\ Visual inspection}

Visual inspection was conducted to check the compatibility between drug and excipients in the film when stored in a glass container at room temperature for 3 months. Throughout the examination, there was no change in the color of the film, indicating that drug and excipients are quite compatible.

FTIR spectroscopy

Domperidone, $\beta$-cyclodextrin and optimized SD were characterized by FTIR spectrum by $\mathrm{KBr}$ disc method and are shown in Fig. 5 . The

Table 9: Drug release characteristics of formulations

\begin{tabular}{|c|c|c|c|c|c|c|}
\hline Formulation code & Polymer concentration $(\%)$ & $T_{50}(\min )$ & $T_{80}(\min )$ & $\mathrm{K}_{0}(\mathrm{mg} / \mathrm{h})$ & $\mathbf{K}_{1} / \mathbf{h}$ & 'n' in Peppas equation \\
\hline FH 1 & 20 & 20 & $>60$ & 0.8641 & 0.0065 & 0.3375 \\
\hline FH 2 & 17.5 & 19.5 & $>60$ & 1.0815 & 0.0098 & 0.3727 \\
\hline FH 3 & 15 & 15 & 30 & 1.2798 & 0.0144 & 0.4066 \\
\hline $\mathrm{FH} 4$ & 12.5 & 5.5 & 28 & 1.2799 & 0.0157 & 0.3885 \\
\hline FH 5 & 10 & 4.25 & 22 & 1.2841 & 0.0185 & 0.3609 \\
\hline
\end{tabular}

Table 10: Drug release characteristics of formulations

\begin{tabular}{|c|c|c|c|c|c|c|}
\hline Formulation code & Polymer concentration $(\%)$ & $\mathrm{T}_{50}(\mathrm{~min})$ & $\mathrm{T}_{80}(\mathrm{~min})$ & $\mathrm{K}_{0}(\mathrm{mg} / \mathrm{h})$ & $\mathbf{K}_{1} / \mathbf{h}$ & 'n' in Peppas equation \\
\hline FG 1 & 20 & 10 & $>60$ & 1.1382 & 0.0108 & 0.4059 \\
\hline FG 2 & 17.5 & 9.5 & 35 & 1.3175 & 0.0158 & 0.4178 \\
\hline FG 3 & 15 & 12.5 & 32 & 1.2843 & 0.0161 & 0.3788 \\
\hline FG 4 & 12.5 & 5 & 26 & 1.2723 & 0.0170 & 0.3673 \\
\hline FG 5 & 10 & 4.25 & 18 & 1.3868 & 0.0297 & 0.3693 \\
\hline FHG & $5+5$ & 4 & 12.5 & 1.4111 & 0.0439 & 0.3737 \\
\hline
\end{tabular}

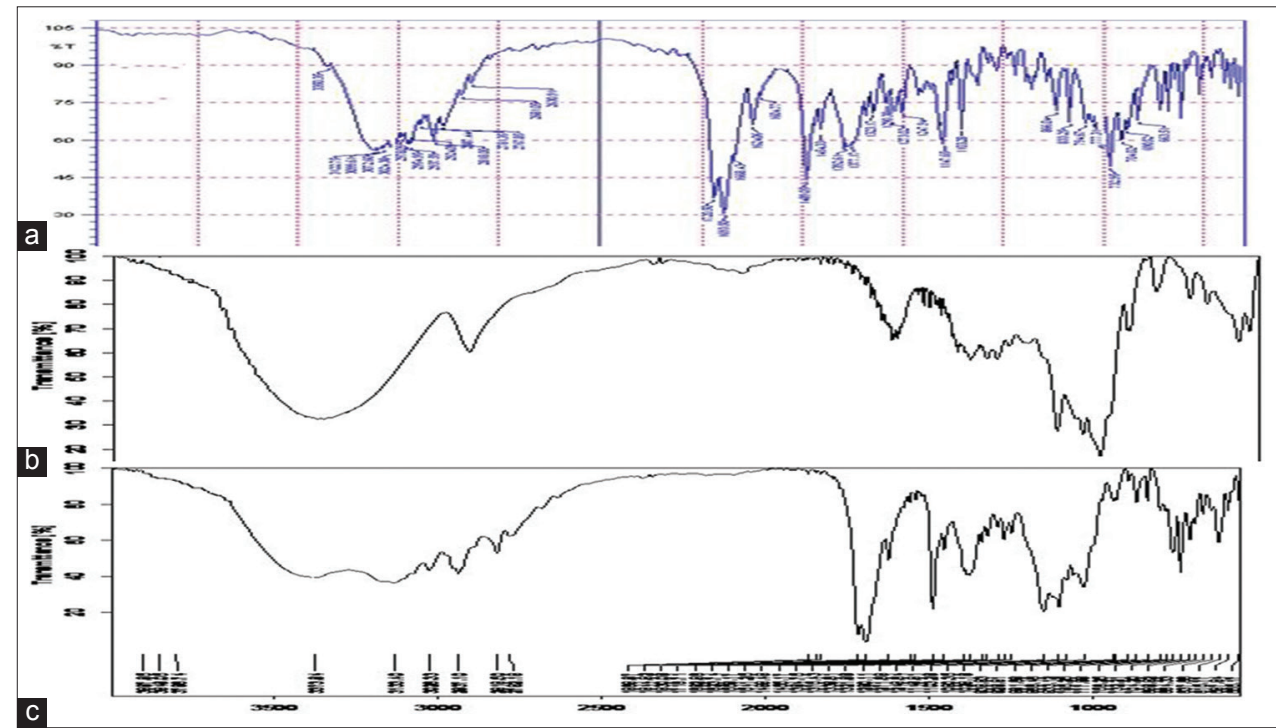

Fig. 5: FTIR spectra of (a) Domperidone (b) $\beta$-cyclodextrin and (c) SDK3 
FTIR spectrum of pure domperidone $[20,28,29]$ showed characteristic $\mathrm{N}-\mathrm{H}$ stretch at $3364.91 \mathrm{~cm}^{-1}$ and strong $\mathrm{C}=0$ stretch at $1694.45 \mathrm{~cm}^{-1}$, indicating the presence of $-\mathrm{CONH}$ group, asymmetric $=\mathrm{C}-\mathrm{H}$ stretching at $3072.20 \mathrm{~cm}^{-1}$, symmetric $-\mathrm{C}-\mathrm{H}$ stretching at $2955.19 \mathrm{~cm}^{-1}$, aromatic $\mathrm{C}-\mathrm{H}$ stretching at $3024.18 \mathrm{~cm}^{-1},-\mathrm{C}=\mathrm{C}$ - stretch at $1622.48 \mathrm{~cm}^{-1}$, and $\mathrm{C}-\mathrm{Cl}$ stretch denoting the presence of alkyl halide at $731.50 \mathrm{~cm}^{-1}$.

The FTIR spectrum of $\beta$-cyclodextrin showed characteristic N-H stretch at $3382.52 \mathrm{~cm}^{-1}$ and strong $\mathrm{C}=0$ stretch at $1636.50 \mathrm{~cm}^{-1}$, indicating the presence of $-\mathrm{CONH}$ group, asymmetric $=\mathrm{C}-\mathrm{H}$ stretching at $2924.32 \mathrm{~cm}^{-1}$, symmetric -C-H stretching at $2955.19 \mathrm{~cm}^{-1}$, aromatic C-H stretching at $3044.18 \mathrm{~cm}^{-1},-\mathrm{C}=\mathrm{C}$ - stretch at $1749.46 \mathrm{~cm}^{-1}$, and $\mathrm{C}-\mathrm{Cl}$ stretch denoting the presence of alkyl halide at 947.12 and $757.46 \mathrm{~cm}^{-1}$

The spectra of SD showed similar characteristic stretches present in the pure drug such as $\mathrm{N}-\mathrm{H}$ stretch at $3373.92 \mathrm{~cm}^{-1}$ and asymmetric $=\mathrm{C}-\mathrm{H}$ stretching at $3026.33 \mathrm{~cm}^{-1}$, symmetric $-\mathrm{C}-\mathrm{H}$ stretching at $2937.10 \mathrm{~cm}^{-1},-\mathrm{C}=\mathrm{C}$ - stretch at $1559.17 \mathrm{~cm}^{-1}$, and $\mathrm{C}-\mathrm{Cl}$ stretch denoting the presence of alkyl halide at $756.26 \mathrm{~cm}^{-1}$. However, the spectrum did not show any additional peak indicating the absences of any chemical reaction between the domperidone and $\beta$-cyclodextrin $[14,15]$.

DSC

DSC thermograms of domperidone, $\beta$-cyclodextrin, HPMC K15M, gellan gum, optimized SD and FDFs are shown in Fig. 6 corresponding's to the melting point of the pure drug in its official monograph as per USP. The melting endothermic peak of domperidone in its pure form was observed at $245.98^{\circ} \mathrm{C}$ with onset at $250.3^{\circ} \mathrm{C}$ and $\Delta \mathrm{H}$ of $6.42 \mathrm{~mJ} / \mathrm{mg}$. $\beta$-cyclodextrin showed a sharp endothermic peak at $91.27^{\circ} \mathrm{C}$ with onset at $252.37^{\circ} \mathrm{C}$ with enthalpy of fusion $(\Delta \mathrm{H})$ of $161.10 \mathrm{~mJ} / \mathrm{mg}$ corresponding with the $\beta$-cyclodextrin melting temperature.

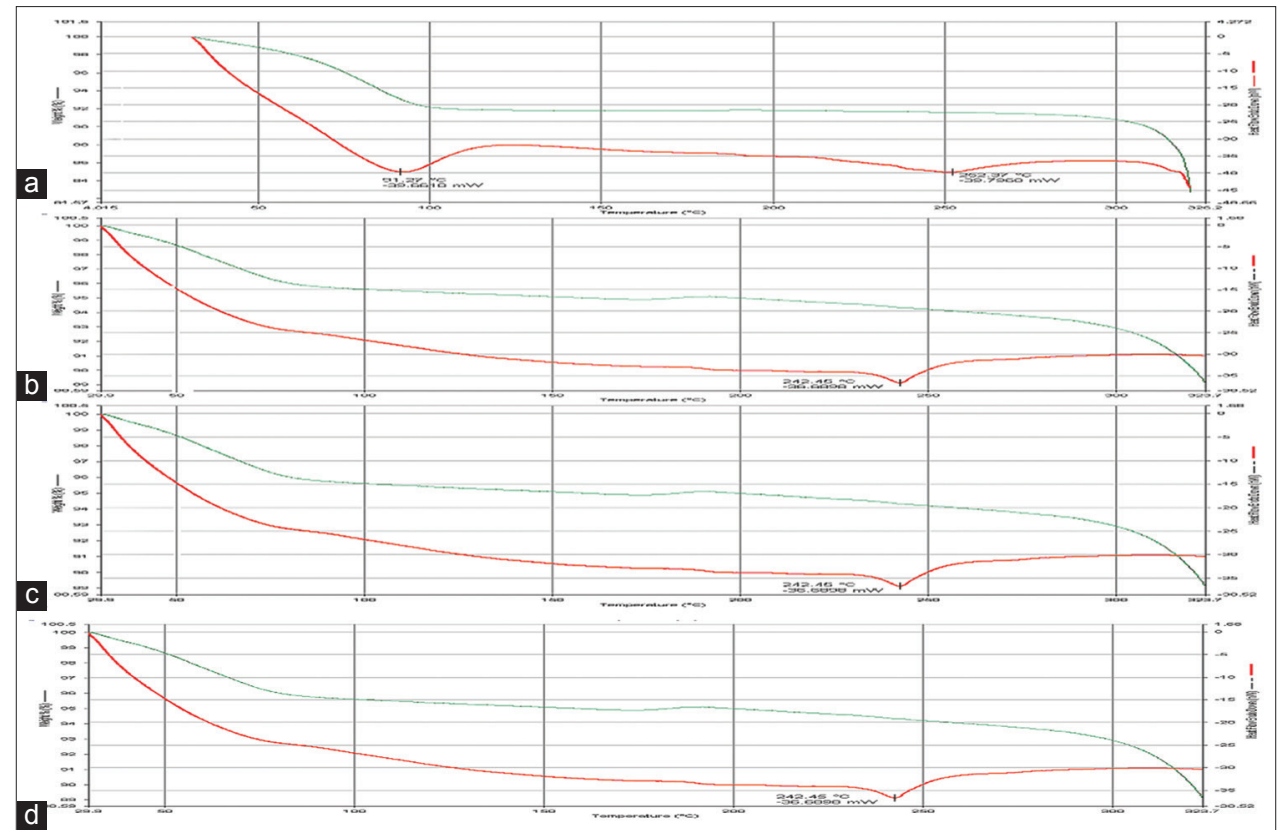

Fig. 6: Differential scanning calorimetry thermograms of (a) Domperidone, (b) $\beta$-cyclodextrin, and (c) SDK3, and (d) FDF FHG

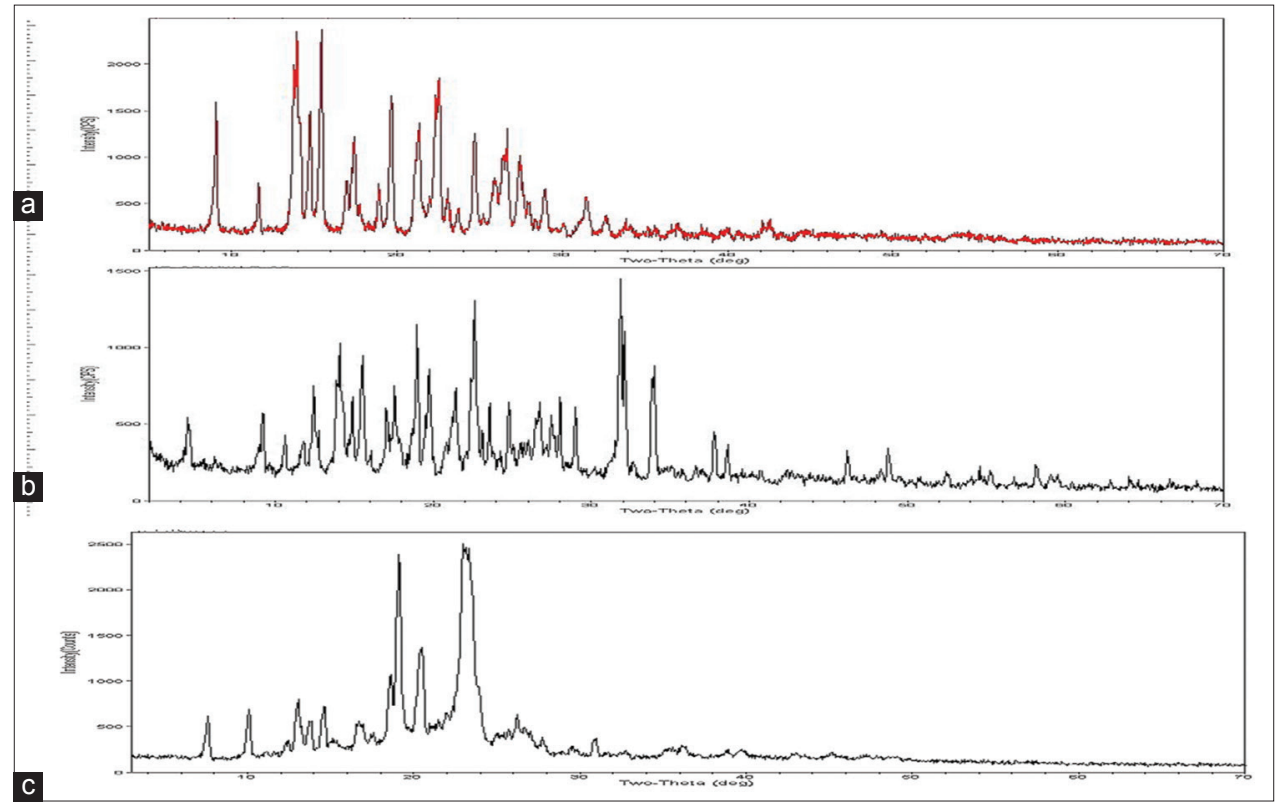

Fig. 7: Dissolution profiles of optimized formulation FHG on stability 
From the curves of optimized SD and FDFs containing domperidone and $\beta$-cyclodextrin along with HPMC K15M and gellan gum, it was observed that there was endothermic peak of SD $242.45^{\circ} \mathrm{C}$ and for FDFs $243.19^{\circ} \mathrm{C}$ no peak corresponding to melting point of the drug suggesting amorphous form of domperidone in the SD as well as FDFs.

\section{XRD analysis}

The X-ray diffractograms of domperidone, $\beta$-cyclodextrin and optimized SD are shown in Fig. 7. The X-ray diffractograms of domperidone and $\beta$-cyclodextrin showed characteristic sharp intensity diffraction peaks at $8^{\circ} \mathrm{C}$ equivalent values of $12^{\circ} \mathrm{C}, 14^{\circ} \mathrm{C}, 16^{\circ} \mathrm{C}, 18^{\circ} \mathrm{C}, 20^{\circ} \mathrm{C}, 24^{\circ} \mathrm{C}$, and $28^{\circ} \mathrm{C}$ which reflected the crystalline nature of drug.

The optimized SD showed a reduction in peak intensity when compared to the pure drug domperidone which was very negligible. The results showed that the SD converted the drug which processed a strong crystal habit into a totally amorphous one and was supported by DSC. As a result of amorphization and substantial increase in surface area, drug particles acquired high internal energy necessary for their enhancing wetting and dissolution of the FDFs.

\section{Stability studies}

The optimized formulation FHG showed good in vitro performance when subjected to stability studies. The stability studies were carried out at room temperature on the physical properties, drug content and drug release from the FDFs. The results of these studies are given in Table 11 and Fig. 8. The results thus indicated that there were no visible and physical changes observed in the frequency discrimination even after storage. Weight variation, thickness, surface $\mathrm{pH}$, folding endurance, swelling property, transparency, disintegration time, and elongation were found to be uniform before and after storage at different time period. It was observed that there was no significant change in drug

Table 11: Stability studies of optimized formulation FHG

\begin{tabular}{|c|c|c|c|}
\hline \multirow{2}{*}{$\begin{array}{l}\text { Evaluation } \\
\text { parameters }\end{array}$} & \multicolumn{3}{|l|}{ FHG } \\
\hline & $\begin{array}{l}\text { Before } \\
\text { Storage }\end{array}$ & $\begin{array}{l}\text { After } \\
\text { 1months }\end{array}$ & $\begin{array}{l}\text { After } \\
\text { 3months }\end{array}$ \\
\hline$\%$ Drug Content $^{\mathrm{a}}$ & $98.9 \pm 0.88$ & $98.04 \pm 0.74$ & $98.69 \pm 0.98$ \\
\hline Thickness $^{\mathrm{b}}$ & $0.22 \pm 0.05$ & $0.21 \pm 0.15$ & $0.22 \pm 0.09$ \\
\hline Weight variation $^{\mathrm{b}}$ & $58.3 \pm 0.52$ & $59.18 \pm 0.96$ & $57.89 \pm 0.88$ \\
\hline Surface $\mathrm{pH}^{\mathrm{a}}$ & $6.43 \pm 0.04$ & $6.45 \pm 0.11$ & $6.35 \pm 0.16$ \\
\hline Folding Endurance $^{\mathrm{a}}$ & $308 \pm 0.53$ & $309 \pm 0.52$ & $309 \pm 0.34$ \\
\hline Swelling property ${ }^{\mathrm{a}}$ & $0.86 \pm 0.06$ & $0.84 \pm 0.04$ & $0.83 \pm 0.08$ \\
\hline Transparency ${ }^{\mathrm{a}}$ & Transparent & Transparent & Transparent \\
\hline Disintegration time $^{a}$ & $27 \pm 0.45$ & $26.0 \pm 0.49$ & $27.0 \pm 0.34$ \\
\hline$\%$ Elongation $^{a}$ & $28.93 \pm 0.49$ & $54.65 \pm 0.32$ & $25.6 \pm 0.96$ \\
\hline
\end{tabular}

Where: ${ }^{a}$ mean \pm s.d. $(n=3)$ of domperidone FDFs, ${ }^{b}$ mean \pm s.d. $(n=10)$ of domperidone FDFs

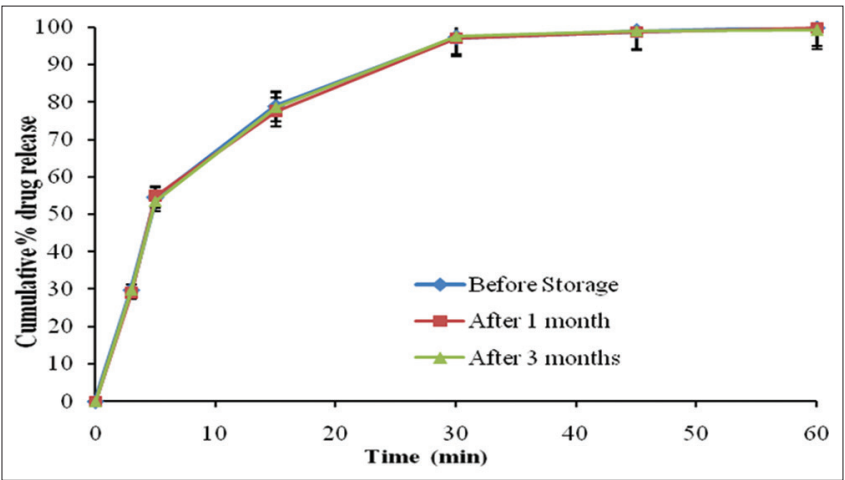

Fig. 8: Dissolution profiles of optimized formulation FHG on stability release from the FHG FDFs. Therefore, the drug release characteristics of FDFs designed were found to be quite stable.

\section{CONCLUSIONS}

Solid dosage forms that can be dissolved or suspended with water in the mouth for easy swallowing are highly desirable for the pediatric and geriatric population as well as other patients who prefer the convenience of the readily administered dosage form. In present work, the solubility of domperidone was initially enhanced by the kneading method (1:0.5, 1:0.75, and 1:1) using $\beta$-cyclodextrin (inclusion). The solubility of domperidone was enhanced by increasing the concentration of $\beta$-cyclodextrins, and the complete drug release was achieved $98.86 \%$ within $30 \mathrm{~min}$; hence, this ratio is taken for further development of fast dissolving films (FDFs). The FDFs of domperidone were prepared successfully by incorporating the optimized SD SDK3 by solvent casting method using HPMC K15 and gellan gum in different concentrations $(10 \%, 17.5 \%, 15 \%, 12.5 \%$, and $20 \% \mathrm{w} / \mathrm{w})$. From the optimized concentrations of these polymers, another formulation was developed by taking the above two film-forming polymers in combination ( $5 \%$ of HPMC K15 and gellan gum). The FDFs prepared with combination of polymers shown better result when compared with the optimized formulations with individual polymer FH5 and FG5. Solvent casting method was found to be the best approach in the formulation of FDFs. From the study, it was concluded that the formulation prepared with equal compositions of HPMC K15 and gellan gum enhanced the drug release rate. The optimized formulation FHG has been found to be stable. The prepared film also gives benefit in terms of patient compliance, avoids first-pass effect, shows rapid onset of action, increased bioavailability, low side effects and good stability which make these films popular as a novel dosage form. Thus, satisfactory FDFs of domperidone for large scale production are feasible. From the entire study, we can conclude that natural polymers such as gellan gum in single or in combination can be used as film-forming polymer in the formulation of FDFs of domperidone since the primary ingredients are inexpensive, devoid of toxicity, biocompatible, biodegradable, and easy to manufacture.

\section{ACKNOWLEDGMENT}

All the authors were thankful to Maharajah's College of Pharmacy, Vizianagaram, for granting permission to use its facilities to carry out the research work and also thankful to Principal, Dr. P. Udaya Shankar for encouragement and support in carrying out the work. Mr. Satya Narayana DSC Purse, Andhra University, Visakhapatnam, and his team for their extensive support in conducting DSC, FTIR and XRD studies. Dr. Kovvasu Surya Prakash has reviewed the manuscript.

\section{AUTHORS' CONTRIBUTIONS}

Dr. Saripilli Rajeswari the guarantor of this study has designed and supervised the experimental process. Ms. Patibandla Sameera have carried out the experiments and analyzed the results. Dr. K. Hari, Ms. Patibandla Sameera and Ms. Konchada Alekhya have contributed in preparation and revision of the manuscript.

\section{CONFLICTS OF INTEREST}

All authors have no conflicts of interest.

\section{REFERENCES}

1. Kunte S, Tandale P. Fast dissolving strips: A novel approach for the delivery of verapamil. J Pharm Bioallied Sci 2010;2:325-8.

2. Sarita R, Raju L, Vinay D, Virendra Y. Formulation and evaluation of domperidone fast dissolving film by using different polymers. Int $\mathrm{J}$ Pharma Res Health Sci 2014;2:374-8.

3. Khatoon N, Raghavendra P. Overview on fast dissolving oral films. Int J Chem Pharm Sci 2013;1:63-75.

4. Subhash V, Basanti G, Guru S, Madhusudhan R. Overview on fast dissolving films. Int J Pharm Pharm Sci 2010;2:29-33.

5. Vijaya K, Ravishanker D, Rohini P, Subbarao M. Formulation and 
in vitro evaluation of sumatriptan succinate oral thin films. Indo Am J Pharm Res 2013;3:3016-25.

6. Patel N, Pancholi S. An overview on sublingual route for systemic drug delivery. Int J Res Pharm Biomed Sci 2012;3:913-23.

7. Dey P, Ghosh A. Wafers: An innovative advancement of oro-dispersible films. Int J Appl Pharm 2016;8:1-7.

8. Aggarwal J, Singh G, Saini S, Rana A. Fast dissolving films: A novel approach to oral drug delivery. Int Res J Pharm 2011;2:69-74.

9. Arun A, Chandra A, Vijay S, Kamla P. Fast dissolving oral films: An innovative drug delivery system and dosage form. Int J Chem Tech Res 2010;2:576-83.

10. Bala R, Pawar P, Khanna S, Arora S. Orally dissolving strips: A new approach to oral drug delivery system. Int J Pharma Investig 2013;3:67-76.

11. Hari K, Rajeswari S, Murthy KV. Preparation and evaluation of drotaverine $\mathrm{HCl}$ oral disintegrating tablets using solid mixture technique. Asian J Pharm Clin Res 2018;11:289-97.

12. Available from: http://www.emedicinehealth.com/drug-motilium/ article em.htm. [Last accessed on 2016 Oct 05].

13. Joshi P, Patel H, Patel V, Panchal R. Formulation and evaluation of mouth dissolving film of domperidone. J Pharm Bioall Sci 2012;4:108-9.

14. Ghodkea D, Nakhat P, Yeole P, Naikwade N, Magdum S, Shah R. Preparation and characterization of domperidone inclusion complexes with cyclodextrin: Influence of preparation method. Int J Pharm Res 2009;8:145-51.

15. Essa E, Balata G. Preparation and characterization of domperidone solid dispersions. Pak J Pharm Sci 2012;25:783-91.

16. Bahim E, El-Faham T, Mohammed F, El-Eraky N. Enhancement of solubility and dissolution rate of domperidone by utilizing different techniques. Bull Pharm Sci Assiut Univ 2011;34:105-20.

17. Chowdary KP, Prakasarao KS, Amar A. A factorial study on the effects of cyclodextrins, poloxamer 407 and PVP on the solubility and dissolution rate of valsartan. Int J Pharm Pharm Sci 2012;4:285-7.

18. Chowdary KPR, Prakasarao KS. Formulation development of etoricoxib tablets employing HP $\beta$ cyclodextrin-poloxamer 407- PVP K30: A factorial study. Asian J Pharm Clin Res 2012;5:161-4.

19. Chowdary KP, Prakasarao KS. Individual and combined effects of cyclodextrins, poloxamer and PVP on the solubility and dissolution rate of BCS class II drugs. Asian J Chem 2011;23:4520-4.

20. Anwar D, Ashok P, Minal B, Nidhi S, Naresh G. Design and development of nicotiana tabacum film using factorial design. Int $\mathrm{J}$ Pharm Pharm Sci 2016;8:115-23.

21. Ghada EY, Haidy AA. Design and evaluation of fast dissolving oro-dispersible films of metoclopramide hydrochloride using 32 multifactorial designs. Int J Pharm Pharm Sci 2016;8:218-22.

22. Shah T, Amin A, Parikh J, Parikh R. Process optimization and characterization of poloxamer solid dispersions of a poorly water soluble drug. AAPS Pharm Sci Tech 2007;8:E18-24.

23. Pathan A, Gupta M, Jain N, Dubey A, Agarwal A. formulation and evaluation of fast dissolving oral film of promethazine hydrochloride using different surfactant. J Innov Pharm Biol Sci 2016;3:74-84.

24. Anil M, Desai R. Formulation, optimization and evaluation of mouth dissolving film of nifedipine by using design of experiment. Asian J Pharm Sci 2016;2:73-7.

25. Rajeshwar V. Formulation and evaluation of rapid dissolving films of pravastatin sodium. Int J Biomed Adv Res 2015;6:594-8.

26. Higuchi TJ. Mechanism of sustained-action medication. Theoretical analysis of rate of release of solid drugs dispersed in solid matrices. Pharm Sci 1963;52:1145.

27. Ritger PL, Peppas NA. A simple equation for description of solute release II. Fickian and anomalous release from swellable devices. J Control Release 1987;5:37.

28. Mahajan A, Chhabra N, Aggarwal G. Formulation and characterization of fast dissolving buccal films: A review. Der Pharm Lett 2011;3:158-60.

29. Ravi S, Ramesh D. Formulation and evaluation of domperidone fast dissolving tablets using Plantago ovata mucilage. Int J Pharm Sci Res 2013;4:3489-93. 